Role of agricultural engineering in environmental and sustainable development for the valley and delta areas: 1555 - 1571

\title{
STUDY OF SOME ENGINEERING FACTORS CONCERNING THE PERFORMANCE OF THE AFFECTING TOOL IN CROP RESIDUES SHREDDER
}

* Prof.Dr /Ahmed El-Raie E. Suliman. * Prof.Dr./ Gamal El-Deen Mohamed Nasr ** Dr./ Magdy Ahmed Baiomy

*** Dr./ Abdelraouf Ramadan Eid

\section{ABSTRACT}

The aim of present work is improving the performance of the crop residues shredder by study of some engineering factors concerning the performance of the affecting tool. The items to achieve the aim of the present study are:(1) Evaluation of shredder performance before development(2)Manufacture of cutting knives from local materials.(3)Shredder performance analysis in cutting of cotton stalks (4)Shredder performance analysis in cutting of rice straw (5)Cost analysis of cutting operation. From the above mentioned study, it can recommend the following points for farmer or producer or user following the mentioned order has all the choices according to the prevailing production conditions; 1- The proper selection of new material leads to decrease the sharp edge angle of modified knives to $20^{\circ}$ degree without deformation. 2- Maximum cutting efficiency for cotton stalks was $86.4 \%$ at $1 \mathrm{~mm}$ clearance distance.,20 $20^{\circ}$ degree knife edge angle and $1600 \mathrm{rpm}$ cutting drum speed.3- Minimum fuel consumption rate for cotton stalks was $2.48 \mathrm{~L} / \mathrm{h}$ at $1 \mathrm{~mm}$ clearance distance, $20^{\circ}$ degree knife edge angle. 4Maximum machine production for cotton stalks was $1.4 \mathrm{ton} / \mathrm{h}$ at following factors:5 mm clearance distance, at $20^{\circ}$ degree knife edge angle and 1600 rpm cutting drum speed.5-Maximum cutting efficiency for rice straw was $45.6 \%$ at $1 \mathrm{~mm}$ clearance distance.,20 degree knife edge angle ,1600 rpm cutting drum speed. 6- Minimum fuel consumption rate for rice straw was $3.51 \mathrm{~L} / \mathrm{h}$ at $1 \mathrm{~mm}$ clearance distance, $20^{\circ}$ degree knife edge angle.7-Maximum machine production for rice straw was 0.99 ton $/ \mathrm{h}$ at following factors: $1 \mathrm{~mm}$ clearance distance.,20 degree knife edge angle 1600 rpm cutting drum speed.8-Cutting operation cost is 27.5 L.E./h.

\footnotetext{
*Prof. of Agric. Eng , Fac. of Agric., Cairo Univ. $\quad * *$ Senior Res., Agric. Eng. Res.Inst.(AEnRI) Agric. Research Center $\quad * * *$ Researcher at Water Relations and Field Irrigation Department, National Research Center - Dokki - Giza- Egypt.
} 


\section{INTRODUCTION}

The quantity of crop residues in Egypt was determined to be about
25.4 million $\mathrm{Mg}$ /year, beside 4 million $\mathrm{Mg} /$ year of horticultural
according to the statistical survey of the Egyptian Ministry of Agriculture (2009)(in Arabic). A bad effect on economic, environment, public health and others, can be done by increasing crop residues quantities of all kinds and forms if doesn't be treated in suitable ways. The mechanical treatment by cutting or grinding for crop residues are the most important and primary step should be done to make it great useful. In Egypt there are three types of cutting machines for cutting crop residues and the most current models are cylinder-type cutterheads but there are some disadvantages of shredder are: 1-Low cutting efficiency.(percentage of weight of suitable length for compost and fodder). 2- Low productivity. 3- High fuel consumption. The aim of present work is improving the performance of the crop residues shredder by study of some engineering factors concerning the performance of the affecting tool. Hashish (1981) stated that increasing fodder production from residues such as cotton stalks by crushing or milling them alone as roughages or together with other fodder materials. In addition, protein substitutes can be added to raise their nutritive value. In addition, the same author determined the lengths of the residues accepted by the animals as $2.54-3.81 \mathrm{~cm}$ and sometimes reached $0.52 \mathrm{~cm}$, length. He also mentioned that the equipment remove the outer layers of the stalks which were harmful to the animal. Prasad and Gupta (2005) stated that a knife approach angle of 32 degree was observed to be optimum corresponding to minimum value of energy requirements for cutting maize stalk. Sverker (1987). Showed that a large edge angle will require higher cutting force and more cutting energy. They added that the cutting force linearly increases with the increase in edge angle. Ige and Finner (1976b) stated that the effect of the clearance distance is reduced to that of a simple cantilever beam. Before shearing, the knife usually bends the forge over shear-bar. Mathematically, the energy used for bending the forage is thus super-imposed onto the shearing energy. If the system was assumed to be represented by that of a cantilever beam, this additional energy would be proportional to the clearance distance to the third 
power. If it is assumed to be the bending of a plate, where it would be proportional to the clearance distance squared.

\section{MATERIAL AND METHODS}

\section{Material:}

Shredder machine: Specifications of the shredder machine are as follow: a) Cutting cylinder: $70 \mathrm{~cm}$ long and $50 \mathrm{~cm}$ diameter skeleton cylinder with two cutting drum and sixteen cutter knives. b) The knives and the Countershear: The knife and the countershear are two active elements of a cutting device ( chopping cylinder), with the knife being the primary active component. Knife dimensions are $35 \mathrm{~cm}$ long, $7 \mathrm{~cm}$ wide, $0.9 \mathrm{~cm}$ Thickness edge angle 30 degree and Countershear dimensions are $82 \mathrm{~cm}$ long, $6 \mathrm{~cm}$ wide and $0.9 \mathrm{~cm}$ thickness. c) Feeding tray: $120 \mathrm{~cm}$ long, $105 \mathrm{~cm}$ and $72 \mathrm{~cm}$ near and front width, respectively, and $20 \mathrm{~cm}$ side wall height. d) Feeding opening : $61 \mathrm{~cm}$ width x $19 \mathrm{~cm}$ height.

\section{Methods:}

Machine production: Time of chopping was measured by means of a stopwatch to determine the machine production in $\mathrm{Mg} / \mathrm{h}$ (Arif, 1999).

Fuel consumption: The fuel tank was filled to full capacity before and after each trial. A graduated cylinder was used for each test trial to measure the amount of refueling. The rate of fuel consumption was calculated as follow: Fuel consumption = Amount of fuel consumption, L/ Time elapsed, h, L/h ..( 1 ) (Imbabi, 2001)

Cutting efficiency, $\boldsymbol{\eta}_{\mathbf{c}}$ : The cutting length of final product is an important parameter to evaluate the performance of cutting process. Where, the suitable cutting length that can be used to produce the compost and the forage is in the range of $0<\mathrm{L}_{c}<50 \mathrm{~mm}$. There are standard sieves used for segregation of a specific mass, $S_{b}$, from the chopped production to several weights, having cutting length $0<\mathrm{L}_{\mathrm{c}}<50$ $\mathrm{mm}$. Consequently, the cutting efficiency can be calculated as following. $\eta_{c}=S_{a} / S_{b} \times 100 \ldots(2)$

Where: $S_{b}$ is the mass of the chopped production before segregation, $g$; 
$\mathrm{S}_{\mathrm{a}}$ is the mass of the chopped production after segregation of cutting length $0<\mathrm{L}_{\mathrm{c}}<50 \mathrm{~mm}$, g. (Habib, 2002 ).

\section{RESULTS AND DISCUSSION}

\section{Evaluation of Shredder Performance before Development}

Table (1): Shredder performance for cotton stalks before development at $30^{\circ}$ knife edge angle and $4 \mathrm{~mm}$ clearance distance:

\begin{tabular}{||c||c||c||c||c||}
\hline $\begin{array}{c}\text { Cutting drum } \\
\text { speed, rpm }\end{array}$ & $\begin{array}{c}\text { Cutting } \\
\text { efficiency, } \%\end{array}$ & $\begin{array}{c}\text { Fuel } \\
\text { consumption, } / \mathbf{h}\end{array}$ & $\begin{array}{c}\text { Required } \\
\text { power, } \mathbf{k W}\end{array}$ & $\begin{array}{c}\text { Machine } \\
\text { production, } \mathbf{~ g g / h}\end{array}$ \\
\hline \hline 1200 & 30.41 & 5.00 & 15.8 & 0.630 \\
\hline 1300 & 49.68 & 5.33 & 16.84 & 0.700 \\
\hline \hline 1400 & 51.89 & 6.53 & 20.65 & 0.915 \\
\hline 1500 & 62.25 & 7.13 & 22.53 & 1.010 \\
\hline 1600 & 63.83 & 7.66 & 24.40 & 1.150 \\
\hline \hline 1700 & & High vibrations occurred in shredder \\
\hline
\end{tabular}

Table (2) Evaluation of Shredder Performance for rice straw before development at $30^{\circ} \mathrm{knife}$ edge angle and $4 \mathrm{~mm}$ clearance distance:

\begin{tabular}{|c||c|c||c|c|}
\hline $\begin{array}{c}\text { Cutting } \\
\text { drum speed, } \\
\mathbf{r p m}\end{array}$ & $\begin{array}{c}\text { Cutting } \\
\text { efficiency, } \%\end{array}$ & $\begin{array}{c}\text { Fuel } \\
\text { consumption, } \\
\mathbf{l} / \mathbf{h}\end{array}$ & $\begin{array}{c}\text { Required } \\
\text { power, } \\
\mathbf{~ k W}\end{array}$ & $\begin{array}{c}\text { Machine } \\
\text { production, } \\
\mathbf{M g} / \mathbf{h}\end{array}$ \\
\hline 1200 & 15.15 & 3.70 & 11.69 & 0.51 \\
\hline \hline 1300 & 19.70 & 4.11 & 12.98 & 0.58 \\
\hline \hline 1400 & 24.50 & 5.32 & 16.81 & 0.64 \\
\hline 1500 & 26.70 & 6.27 & 19.81 & 0.70 \\
\hline 1600 & 27.00 & 7.00 & 22.12 & 0.79 \\
\hline
\end{tabular}

From the obtained results through out evaluation of shredder performance and cutting knives before development we can determine:

1. The suitable range of cutting drum speed (1300, 1400, 1500 and 1600 rpm) and knife edge angle $\left(20^{\circ}, 25^{\circ}, 30^{\circ}\right.$ and $\left.35^{\circ}\right)$ and clearance distance $(1,3$, and $5 \mathrm{~mm}$ ).

2. Maximum values of machine production, fuel consumption and cutting efficiency are indicator for the development or not.

3. Disadvantages of original knives material where wear resistance of this material is very low beside low impact value, decreasing in this 
values this means it is difficult to make small angles, with small angles we can enhance the cutting efficiency and fuel consumption and machine production.

\section{Manufacture of Cutting Knives from Local Materials}

After classification, the local materials in Egypt, it was found that the cutting tool can be classified into two main categories. The first one is soft steel, low carbon with carburizing layer, which have a good toughness, so it has a very good impact resistance but, the disadvantage of it that the lifetime depend on carburized layer. The second one is tool steel high carbon, which have a very good wear resistance but have poor toughness. New material will be manufactured by casting to enhance all disadvantages of original knives material.

\section{Shredder Performance Analysis for Cotton Stalks}

Cotton stalks were cut by shredder machine after harvesting cotton crop directly at high moisture content $25.27 \%$ to avoid bad effects which result from staying cotton stalks without cutting and solve the problem before starting.

3.1. Cutting efficiency: Fig. (1) shows that the cutting efficiency increased with increasing cutting drum speed while the cutting efficiency decreased with increasing knife edge angle and the clearance distance between the knife and countershear. The cutting efficiency increased with the increasing cutting drum speed, that is due to an increase in the number of cuts per unit time and this increase the weight of the suitable cutting length for example the cutting efficiency increased from $58.5 \%$ to $86.4 \%$ with increasing cutting drum speed from 1300rpm to $1600 \mathrm{rpm}$ at $1 \mathrm{~mm}$ clearance distance and 20 degree knife edge angle. The cutting efficiency decreased with increasing knife edge angle this may be due to the cutting by shear force turn into cutting by shear force and impact force gradually this due to increasing un-homogeneous of cut lengths the result decreasing in the cutting efficiency, for example, the cutting efficiency decreased from $80.2 \%$ to $70.6 \%$ with increasing knife edge angle from $20^{\circ}$ degree to $35^{\circ}$ degree at $1 \mathrm{~mm}$ clearance distance and 1500 rpm cutting drum speed. The cutting efficiency decreased with increasing clearance distance this may be due to the short branch of cotton stalk pass parallel to the cutting drum being not in the right angle position and it has 

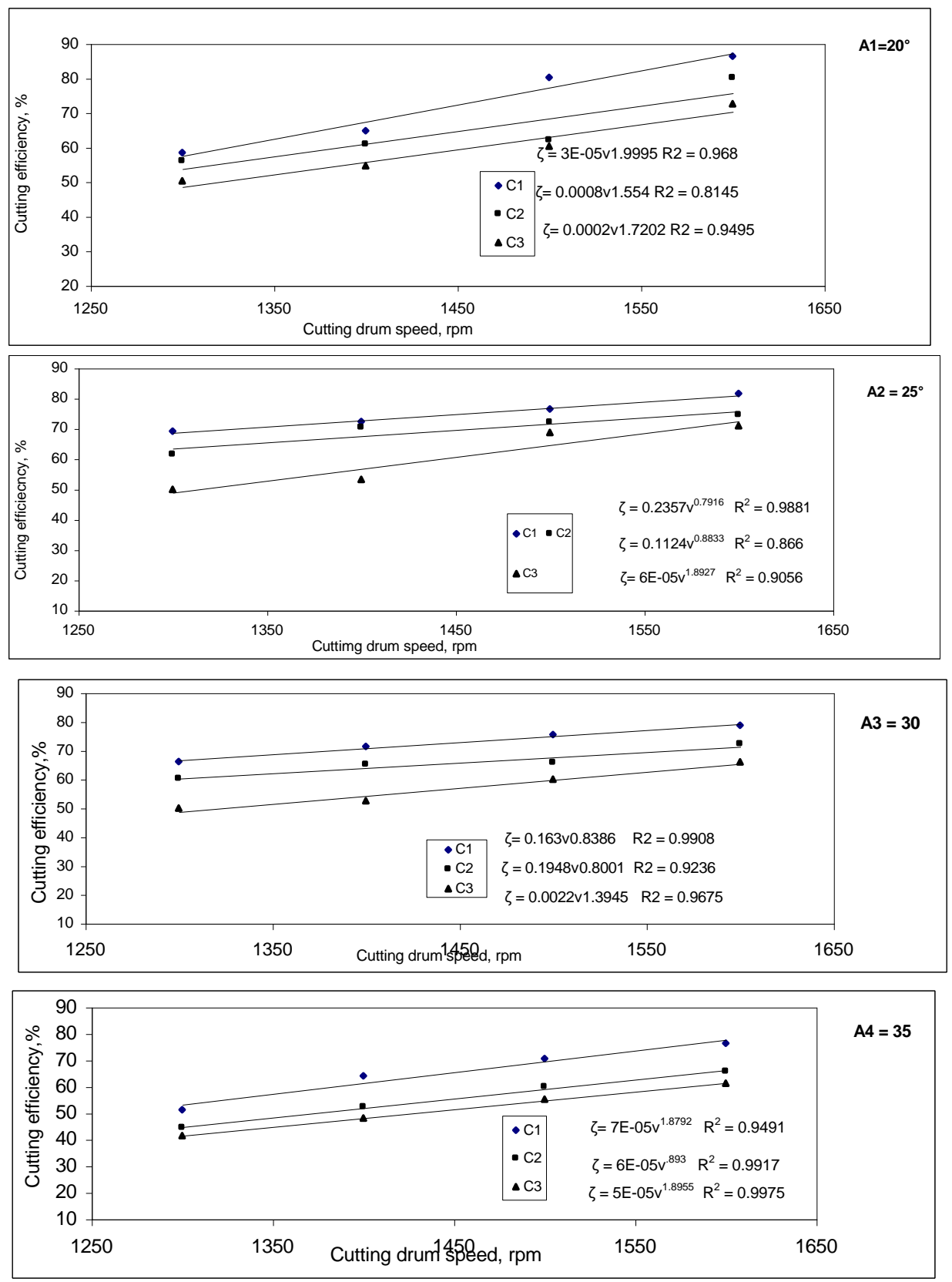

Fig. 1 (A1,A2,A3 and A4); The relation between cutting efficiency and cutting drum speed with different levels of clearance distance (C) $(1,3,5) \mathrm{mm}$ at $20^{\circ}, 25^{\circ} 30^{\circ}, 35^{\circ} \mathrm{knife}$ edge angle (A) at $25.27 \%$ moisture content for cotton stalks. 
small diameter than clearance distance and the result short branch of cotton stalks pass without cut the result decreasing in the cutting efficiency. For example, the cutting efficiency decreased from $58.5 \%$ to $50.3 \%$ with increasing clearance distance from $1 \mathrm{~mm}$ to $5 \mathrm{~mm}$ at $20^{\circ}$ knife edge angle and $1300 \mathrm{rpm}$ cutting drum speed.The general behavior representing the relationship between the cutting efficiency and cutting drum speed is a power model of the form: $\zeta=\mathbf{a} \mathbf{v}^{\mathbf{b}}$.

Where: $\zeta$ is the cutting efficiency, $\% \quad \mathbf{v}$ is cutting drum speed, rpm; $a, b$ are constants.

3.2. Fuel consumption: Table (3) shows that fuel consumption increased with increasing cutting drum speed, knife edge angle and clearance distance. Fuel consumption increased with increasing cutting drum speed this may be due to increasing in amount of material to be cut by increasing cutting drum speed, increase the number of cuts per unit time this required increasing in fuel consumption to (a) compress the material to be cut, (b) shear the material, (c) move the air pumped by the cutterhead, (d) accelerate the cut material, (e) overcome the mechanical losses in the machine. For example, fuel consumption increased from $2.48 \mathrm{l} / \mathrm{h}$ to $5.40 \mathrm{l} / \mathrm{h}$ with increasing cutting drum speed from $1300 \mathrm{rpm}$ to $1600 \mathrm{rpm}$ at $1 \mathrm{~mm}$ clearance distance and $20^{\circ}$ degree knife edge angle .Fuel consumption decreases with decreasing knife edge angle .This may be due to when deeper penetration into the material is required in order to reduce a cut, the main resistance to the cutting may come from the friction forces on the edge and blade sides. A smaller edge angle will reduce this forces, this means reducing in full consumption, e.g. fuel consumption decreased from $7.44 \mathrm{l} / \mathrm{h}$ to $5.401 / \mathrm{h}$ with decreasing knife edge angle from $35^{\circ}$ degree to $20^{\circ}$ degree at $1 \mathrm{~mm}$ clearance distance and $1600 \mathrm{rpm}$ cutting drum speed. This is in agree with the results reported by Sverker (1987), Chattobadhyay and Pandey (1992) and Yumnam and Pratap (1991). Full consumption increased with increasing the clearance distance. That is due to the effect of bending distance, which increased with increasing clearance distance, e.g. full consumption increased from $3.6 \mathrm{l} / \mathrm{h}$ to $4.79 \mathrm{l} / \mathrm{h}$ with increasing clearance distance from $1 \mathrm{~mm}$ to $5 \mathrm{~mm}$ at $1400 \mathrm{rpm}$ cutting drum speed and $20^{\circ}$ degree knife edge angle. This is agreeing with the results reported by Arif (1999) and 
Sverker (1987). The general behavior representing the relationship between the full consumption and cutting drum speed is a power model of the form:

$$
\mathbf{f}=\mathbf{a} \mathbf{v}^{\mathbf{b}} \text {. }
$$

Where: $\mathrm{f}$ is the full consumption, $1 / \mathrm{h} ; \mathrm{v}$ is cutting drum speed, rpm; $\mathrm{a}, \mathrm{b}$ are constants.

Table (3): The relation between cutting drum speed and fuel consumption at different levels of clearance $\left(\mathrm{C}_{1}=1 \mathrm{~mm}, \mathrm{C}_{2}=3 \mathrm{~mm}\right.$, $\left.\mathrm{C}_{3}=5 \mathrm{~mm}\right)$ knife edge angles $\left(20^{\circ} 25^{\circ} 30^{\circ}\right.$ and $\left.35^{\circ}\right)$ and $25.27 \%$ moisture content for cotton stalks.

\begin{tabular}{|c|c|c|c|c|c|c|c|c|}
\hline & \multicolumn{4}{|c|}{$\mathrm{A} 1=20^{\circ}$} & \multicolumn{4}{|c|}{$\mathrm{A} 2=25^{\circ}$} \\
\hline & $\begin{array}{c}\mathrm{V} 1= \\
1300 \\
(\mathrm{rpm}) \\
\end{array}$ & $\begin{array}{l}\mathrm{V} 2= \\
1400 \\
\text { (rpm) }\end{array}$ & $\begin{array}{c}V 3= \\
1500 \\
(\mathrm{rpm}) \\
\end{array}$ & $\begin{array}{l}\mathrm{V} 4= \\
1600 \\
(\mathrm{rpm})\end{array}$ & $\begin{array}{c}\mathrm{V} 1= \\
1300 \\
(\mathrm{rpm}) \\
\end{array}$ & $\begin{array}{l}\mathrm{V} 2= \\
1400 \\
(\mathrm{rpm})\end{array}$ & $\begin{array}{c}\mathrm{V} 3= \\
1500 \\
(\mathrm{rpm})\end{array}$ & $\begin{array}{c}\mathrm{V} 4=160 \\
0 \\
(\mathrm{rpm}) \\
\end{array}$ \\
\hline$C_{1}=1$ & 2.48 & 3.60 & 4.30 & 5.4 & 3.20 & 3.70 & 5.21 & 6.30 \\
\hline $\mathrm{C}_{2}=3$ & 3.37 & 4.20 & 5.23 & 6.10 & 3.90 & 4.80 & 5.52 & 6.71 \\
\hline \multirow[t]{2}{*}{$\mathrm{C}_{3}=5$} & 4.11 & 4.79 & 5.64 & 6.45 & 4.40 & 5.33 & 6.00 & 7.43 \\
\hline & \multicolumn{4}{|c|}{$\mathrm{A}_{3}=30^{\circ}$} & \multicolumn{4}{|c|}{$\mathbf{A}_{4}=35^{\circ}$} \\
\hline$C_{1}=1$ & 4.05 & 4.50 & 5.72 & 7.00 & 4.65 & 5.01 & 6.10 & 7.44 \\
\hline$C_{2}=3$ & 5.38 & 5.84 & 6.15 & 7.43 & 5.71 & 6.43 & 6.62 & 7.85 \\
\hline$C_{3}=5$ & 5.63 & 6.41 & 7.05 & 8.01 & 5.84 & 6.65 & 7.73 & 8.51 \\
\hline
\end{tabular}

$\mathrm{A}=$ Knife edge angle, degree $\mathrm{C}=$ Clearance distance between cutting knife and countershear, $\mathrm{mm}$ $\mathrm{V}=$ Cutting drum speed, rpm

3.3. Machine production: Fig. (2) shows that there no signification effect on the machine production with increasing cutting drum speed while machine production decreased with increasing knife edge angle and clearance distance. In case constancy feeding drum speed, the effecting of cutting drum speed on the machine production is very little whereas, feeding drum speed which control in the amount of raw material which pass through the machine, e. g. the machine production was $1.14,1.12,1.13,1.16$ ton/h with increasing cutting drum speed from $1300,1400,1500,1600 \mathrm{rpm}$, respectively at $1 \mathrm{~mm}$ clearance distance and $20^{\circ}$ degree knife edge angle. This is in agree with the results reported by Kepener $\boldsymbol{e t}$. al (1987). Machine production decrease with very little rate with increasing knife edge angle this may be due to deeper penetration into the material is easy with a small edge angle and its effect is 

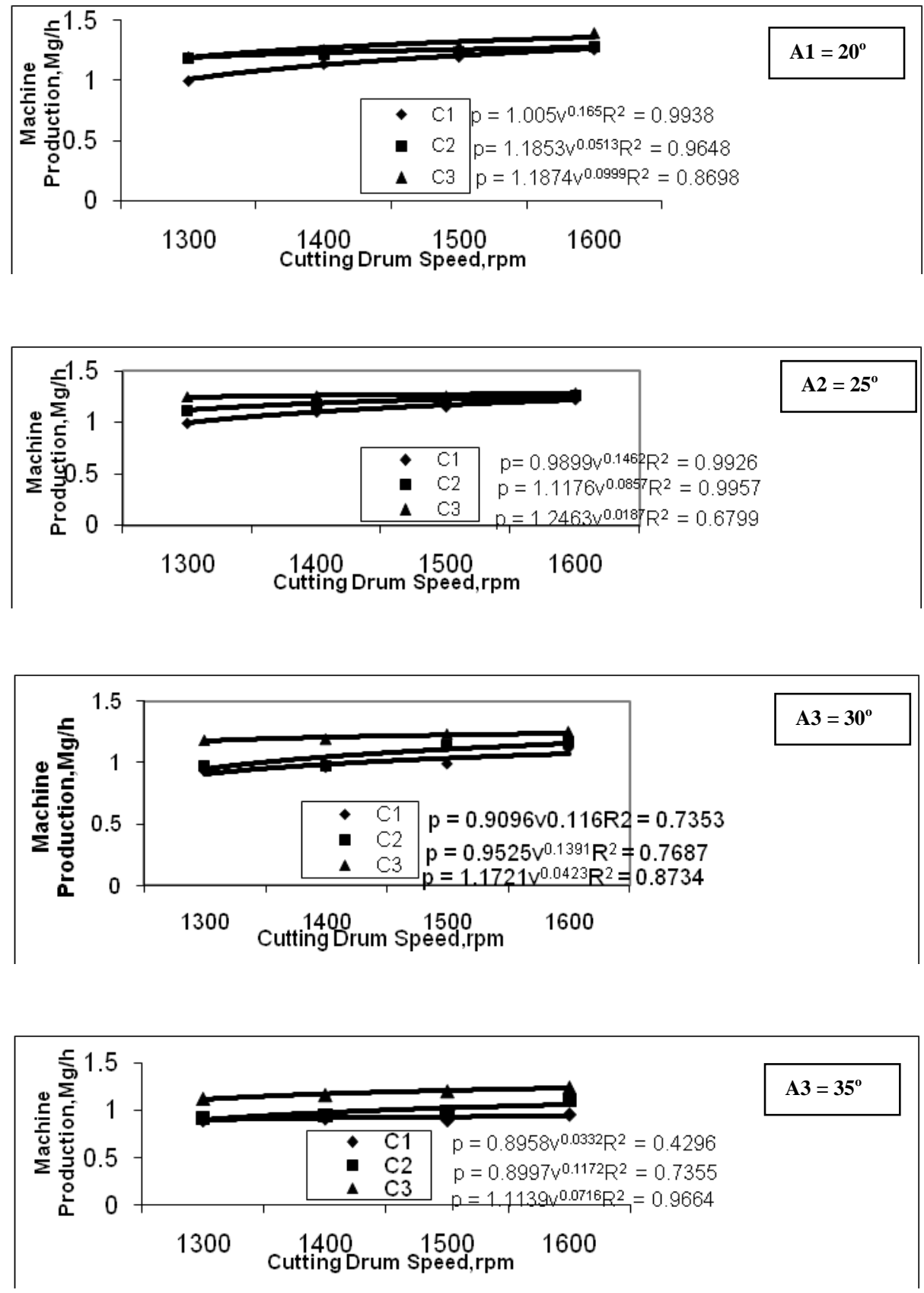

Fig. 2 (A1,A2,A3 and A4); The relation between machine production and cutting drum speed(v) with different levels of clearance distance (C) $(1,3,5) \mathrm{mm}$ at $20^{\circ}, 25^{\circ} 30^{\circ}, 35^{\circ} \mathrm{knife}$ edge angle (A) at $25.27 \%$ moisture content for cotton stalks.

The $17^{\text {th }}$. Annual Conference of the Misr Society of Ag. Eng., 28 October, $2010 \quad-1563-$ 
positively in each cycle, e. g. machine production decreased from 1.14 ton/h to 0.9 ton/h with increasing knife edge angle from $20^{\circ}$ degree to $35^{\circ}$ degree at $1 \mathrm{~mm}$ clearance distance and $1300 \mathrm{rpm}$ cutting drum speed. Machine production increased with increasing clearance distance, this may be due to the short branch pass parallel to the feeding drum being not in the right angle position and it has a small diameter than the clearance distance. e g. the machine production increased from 1.14 ton/h to $1.29 \mathrm{ton} / \mathrm{h}$ with increasing clearance distance from $1 \mathrm{~mm}$ top $5 \mathrm{~mm}$ at $20^{\circ}$ degree knife edge angle and $1300 \mathrm{rpm}$ cutting drum speed. The general behavior representing the relationship between the machine production and cutting drum speed is

$$
\mathbf{p}=\mathbf{a} \mathbf{v}^{\mathbf{b}}
$$

Where: $\mathrm{p}$ is the machine production, ton/h; $\mathrm{v}$ is Cutting drum speed, rpm; $\mathrm{a}, \mathrm{b}$ are Constants. Fig. (2)

\section{Shredder Performance Analysis for Rice Straw}

Rice straw was cut by shredder machine at moisture content $15.46 \%$.

4.1. Cutting efficiency: Fig.(3) shows that the cutting efficiency increased with increasing cutting drum speed while the cutting efficiency decreased with increasing knife edge angle and the clearance distance between the knife and countershear shear pass. The cutting efficiency increased with the increasing cutting drum speed that is due to an increase in the number of cuts per unit time and this increase the weight of the suitable cutting length e.g. the cutting efficiency increased from $33.9 \%$ to $45.6 \%$ with increasing cutting drum speed from $1300 \mathrm{rpm}$ to $1600 \mathrm{rpm}$ at $1 \mathrm{~mm}$ clearance distance and $20^{\circ}$ degree knife edge angle. The cutting efficiency decreased with increasing knife edge angle, this may be due to the cutting by shear force turn into cutting by shear force and impact force gradually this due to increasing un-homogeneous of cut lengths the result decreasing in the cutting efficiency, e.g., the cutting efficiency decreased from $38.0 \%$ to $30.6 \%$ with increasing knife edge angle from $20^{\circ}$ degree to $35^{\circ}$ degree at $1 \mathrm{~mm}$ clearance distance and 1500 rpm cutting drum speed. The cutting efficiency decreased with increasing clearance distance, this may be due to rice straw pass without cut the result decreasing in the cutting efficiency. e.g., the cutting efficiency 
decreased from $33.9 \%$ to $28.9 \%$ with increasing clearance distance from $1 \mathrm{~mm}$ to $5 \mathrm{~mm}$ at 20 knife edge angles and $1300 \mathrm{rpm}$ cutting drum speed. The general behavior representing the relationship between the cutting efficiency and cutting drum speed is a power model of the form: $\zeta=\mathbf{a} \mathbf{v}^{\mathbf{b}} \ldots . . . . . . . . . .(6) \quad$ Where: $\zeta$ is the cutting efficiency, $\% ; \mathrm{v}$ is Cutting drum speed, rpm; $a, b$ are Constants.
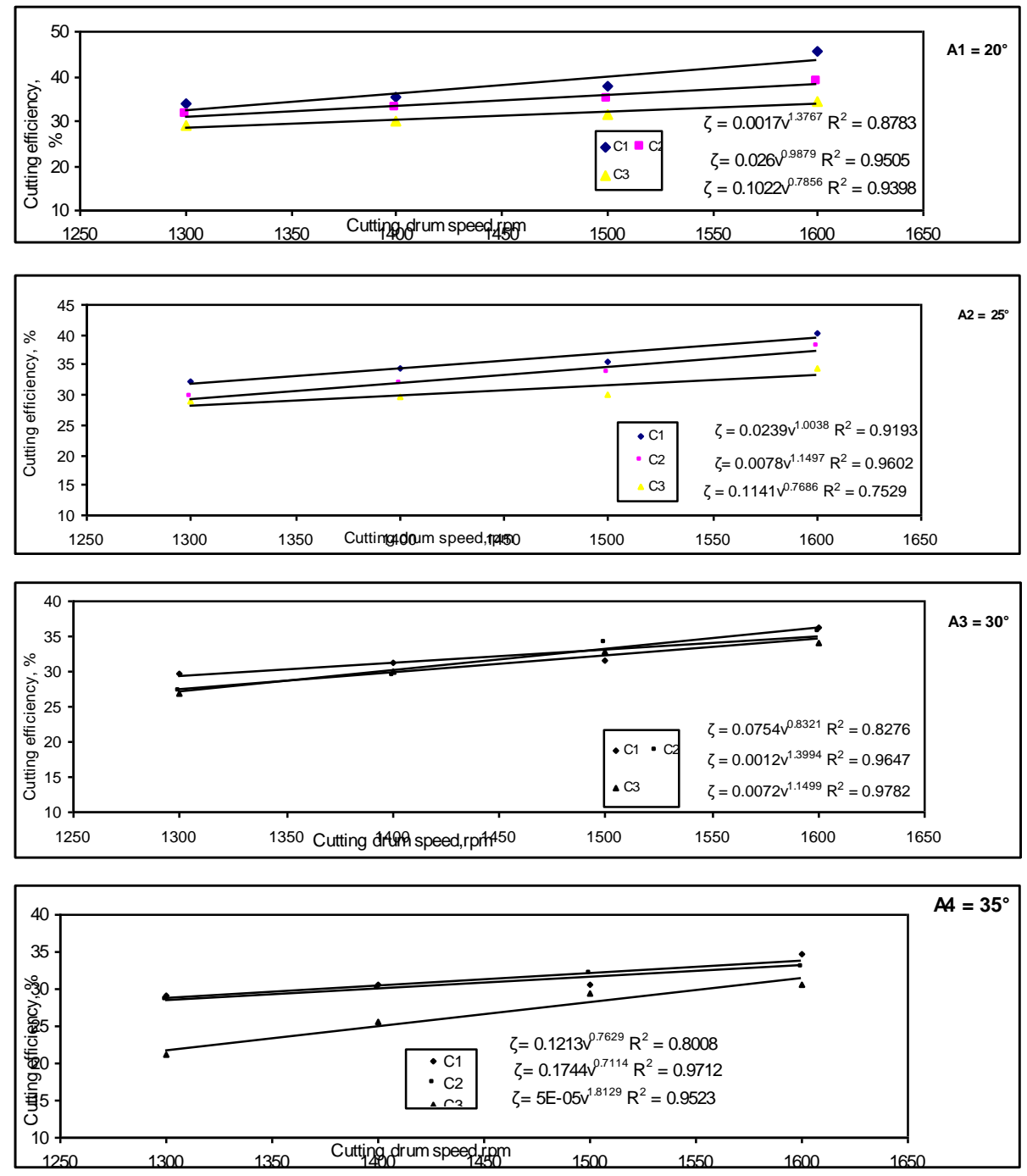

Fig. 3 (A1,A2,A3 and A4); The relation between cutting efficiency and cutting drum speed with different levels of clearance distance (C) $(1,3,5) \mathrm{mm}$ at $20^{\circ}, 25^{\circ} 30^{\circ}, 35^{\circ} \mathrm{knife}$ edge angle (A) at $15.46 \%$ moisture content for rice straw. 
4.2. Fuel consumption: Table (4) show that fuel consumption increased with increasing cutting drum speed, knife edge angle and clearance distance.Fuel consumption increased with increasing cutting drum speed this may be due to increasing in amount of material to be cut by increasing cutting drum speed this increase the number of cuts per unit time and this required increasing in fuel consumption to (a) compress the material to be cut, (b) shear the material, (c) move the air pumped by the cutterhead, (d) accelerate the cut material, (e) overcome the mechanical losses in the machine. e.g., fuel consumption increased from $3.51 \mathrm{l} / \mathrm{h}$ to $6.41 \mathrm{l} / \mathrm{h}$ with increasing cutting drum speed from $1300 \mathrm{rpm}$ to $1600 \mathrm{rpm}$ at $1 \mathrm{~mm}$ clearance distance and $20^{\circ}$ degree knife edge angle. Fuel consumption decreases with decreasing knife edge angle, this may be due to when deeper penetration into the material is required in order to reduce a cut, the main resistance to the cutting may come from the friction forces on the edge and blade sides. A smaller edge angle will reduce this forces, this means reducing in full consumption, e.g. full consumption decreased from $8.03 \mathrm{l} / \mathrm{h}$ to $7.09 \mathrm{l} / \mathrm{h}$ with decreasing knife edge angle from $35^{\circ}$ degree to $20^{\circ}$ degree at $5 \mathrm{~mm}$ clearance distance and $1600 \mathrm{rpm}$ cutting drum speed. This is in agree with the results reported by Sverker (1987), Chattobadhyay and Pandey (1992) and Yumnam and Pratap (1991). Fuel consumption increased with increasing the clearance distance. That is due to the effect of bending distance, which increased with increasing clearance distance. e.g. full consumption increased from $5.43 \mathrm{l} / \mathrm{h}$ to $6.11 \mathrm{l} / \mathrm{h}$ with increasing clearance distance from $1 \mathrm{~mm}$ to 5 $\mathrm{mm}$ at $1500 \mathrm{rpm}$ cutting drum speed and $20^{\circ}$ degree knife edge angle this is in agree with the results reported by Arif (1999) and Sverker (1987). The general behavior representing the relationship between cutting drum speed and the fuel consumption is a power model of the form: $\mathbf{f}=\mathbf{a} \mathbf{v}^{\mathbf{b}}$....(7) Where: $\mathrm{f}$ is fuel consumption, $\mathrm{l} / \mathrm{h}$; $\mathrm{v}$ is cutting drum speed, rpm;a, b are constants.

4.3. Machine Production: Fig.(4) shows that there no signification effect on the machine production with increasing cutting drum speed while machine production decreased with increasing knife edge angle and clearance distance. In case constancy feeding drum speed, the effecting of cutting drum speed on the machine production is very little 
whereas, feeding drum speed which control in the amount of raw material which pass through the machine, e. g.

Table (4): The relation between cutting drum speed and fuel consumption at different levels of clearance $(\mathrm{C} 1=1 \mathrm{~mm}, \mathrm{C} 2=3 \mathrm{~mm}, \mathrm{C} 3=5 \mathrm{~mm})$ knife edge angles $\left(20^{\circ}, 25^{\circ}, 30^{\circ}\right.$ and $\left.35^{\circ}\right)$ and $15.46 \%$ moisture content for rice straw.

\begin{tabular}{|l|c|c|c|c|c|c|c|c|}
\hline & \multicolumn{9}{|c|}{$\mathbf{A}_{\mathbf{1}}=\mathbf{2 0}^{\mathbf{0}}$} & \multicolumn{4}{c|}{$\mathbf{A}_{\mathbf{2}}=\mathbf{2 5}^{\mathbf{0}}$} \\
\cline { 2 - 10 } & $\begin{array}{c}\mathbf{V}_{\mathbf{1}}= \\
\mathbf{1 3 0 0} \\
(\mathbf{r p m})\end{array}$ & $\begin{array}{c}\mathbf{V}_{\mathbf{2}}= \\
\mathbf{1 4 0 0} \\
(\mathbf{r p m})\end{array}$ & $\begin{array}{c}\mathbf{V}_{\mathbf{3}}= \\
\mathbf{1 5 0 0} \\
(\mathbf{r p m})\end{array}$ & $\begin{array}{c}\mathbf{V}_{\mathbf{4}}= \\
\mathbf{1 6 0 0} \\
(\mathbf{r p m})\end{array}$ & $\begin{array}{c}\mathbf{V}_{\mathbf{1}}= \\
\mathbf{1 3 0 0} \\
(\mathbf{r p m})\end{array}$ & $\begin{array}{c}\mathbf{V}_{\mathbf{2}}= \\
\mathbf{1 4 0 0} \\
(\mathbf{r p m})\end{array}$ & $\begin{array}{c}\mathbf{V}_{\mathbf{3}}= \\
\mathbf{1 5 0 0} \\
(\mathbf{r p m})\end{array}$ & $\begin{array}{c}\mathbf{V}_{\mathbf{4}}= \\
\mathbf{1 6 0 0} \\
(\mathbf{r p m})\end{array}$ \\
\hline $\mathbf{C}_{\mathbf{1}}=\mathbf{1 m m}$ & 3.51 & 3.61 & 5.43 & 6.41 & 4.20 & 4.66 & 4.31 & 6.40 \\
\hline $\mathbf{C}_{\mathbf{2}}=\mathbf{3 m m}$ & 3.70 & 4.42 & 5.66 & 6.64 & 4.42 & 5.20 & 4.42 & 6.81 \\
\hline $\mathbf{C}_{\mathbf{3}}=\mathbf{5 m m}$ & 3.87 & 4.10 & 6.11 & 7.09 & 4.72 & 5.35 & 5.80 & 7.33 \\
\hline & \multicolumn{6}{|c|}{$\mathbf{A}_{\mathbf{3}}=\mathbf{3 0}^{\mathbf{0}}$} \\
\hline $\mathbf{C}_{\mathbf{1}}=\mathbf{1 m m}$ & 4.21 & 5.41 & 6.21 & 6.55 & 4.88 & 5.05 & 5.90 & 6.55 \\
\hline $\mathbf{C}_{\mathbf{2}}=\mathbf{3 m m}$ & 4.71 & 5.60 & 6.10 & 6.50 & 4.98 & 5.10 & 6.24 & 7.45 \\
\hline $\mathbf{C}_{\mathbf{3}}=\mathbf{5 m m}$ & 5.00 & 5.70 & 6.41 & 7.77 & 5.32 & 5.61 & 6.52 & 8.03 \\
\hline
\end{tabular}

the machine production was $0.84,0.87,0.85,0.86 \mathrm{ton} / \mathrm{h}$ with increasing cutting drum speed from 1300 to 1400 or 1500 or $1600 \mathrm{rpm}$, respectively at $1 \mathrm{~mm}$ clearance distance and $20^{\circ}$ degree knife edge angle. This is in agreeing with the results reported by Kepener, et. al (1987) . Machine production decreases with very little rate with increasing knife edge angle this may be due to deeper penetration into the material is easy with a small edge angle, and its effect is positively in each cycle, e. g. machine production decreased from 0.86 ton/h to 0.76 ton/h with increasing knife edge angle from $20^{\circ}$ degree to $35^{\circ}$ degree at $5 \mathrm{~mm}$ clearance distance and $1600 \mathrm{rpm}$ cutting drum speed. Machine production decreased with increasing clearance distance, this may be due to many of the material commonly cut are weak in bending, narrowness the clearance distance is very important to prevent bending. If the clearance distance is allowed to increase and approach the thickness of the material being cut, deformation in bending reduces and rice straw contortion around the feeding drum and the cutting drum, so, we have to stop the cutting machine when rice straw rapping or jamming around the feeding drum and the cutting drum, result decreasing in the machine production. e. g. the machine production decreased from 0.93 ton $/ \mathrm{h}$ to $0.86 \mathrm{ton} / \mathrm{h}$ with increasing clearance distance from $1 \mathrm{~mm}$ to $5 \mathrm{~mm}$ at $20^{\circ}$ degree knife 
edge angle and $1600 \mathrm{rpm}$ cutting drum speed. The general behavior representing the relationship between the machine production and cutting drum speed is a power model of the form:

$\mathbf{p}=\mathbf{a} \mathbf{v}^{\mathbf{b}} \ldots . . . . .(8)$ Where: $\mathrm{Y}$ is the machine production, ton/h; $\mathrm{X}$ is Cutting drum speed, rpm; a, b are Constants.

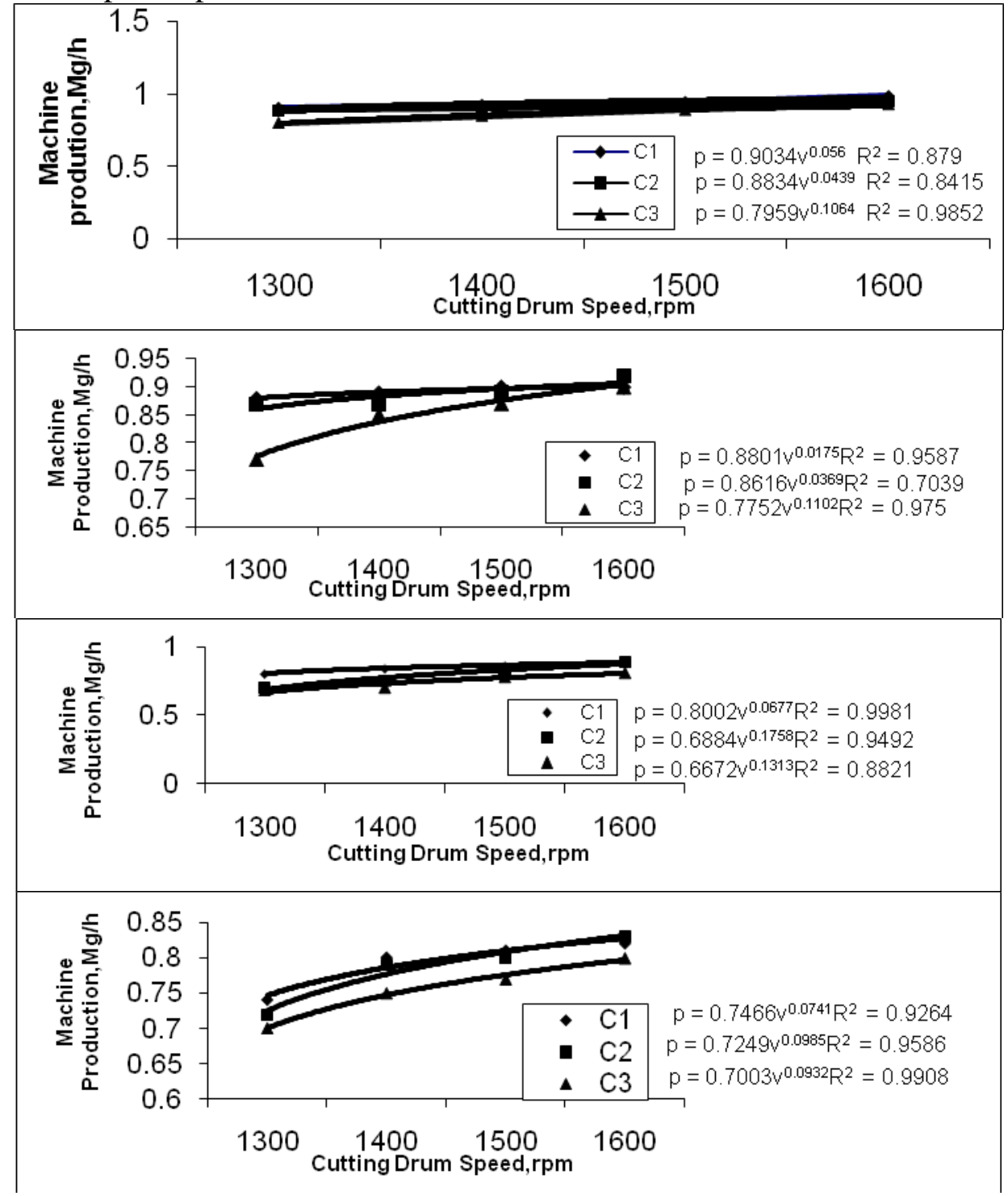

Fig. 4 (A1,A2,A3 and A4); The relation between machine production and cutting drum speed(v) with different levels of clearance distance (C) $(1,3,5) \mathrm{mm}$ at $20^{\circ}, 25^{\circ} 30^{\circ}, 35^{\circ} \mathrm{knife}$ edge angle (A) at $15.46 \%$ moisture content for rice straw. 
4. Cutting operation costs was calculated by (El-Awady 1978) $\mathrm{C}=\mathrm{P} / \mathrm{h}$ $(1 / L+i / 2+t+r)+(0.9 w \times f \times u)+s / 144 \ldots . .(9)$ Where: $\mathbf{C}$ is the total hourly cost, L.E./h; $\mathbf{P}$ is the initial price of the machine 10000 L.E.; $\mathbf{h}$ is the estimated yearly -operating hours $1440 \mathrm{~h}$ (6 month*30day*8hour); L is the estimated Life - expectancy of machine in years; 10 years; $\mathbf{i}$ is the annual interest rate ; (estimated at 0.12); $\mathbf{t}$ is the annual taxes and overheads ; (estimated 0.03) ; $\mathbf{r}$ is the annual rapiers and maintains rate.(10\% of total price ); 1.2 is the A factor accounting for lubrication; $\mathrm{W}$ is the engine power, $60 \mathrm{hp}-\mathrm{f}$ is the Specific fuel consumption, 0.25 $\mathrm{L} / \mathrm{hp} . \mathrm{h}$ and $\mathrm{u}$ is the fuel price, $0.7 \mathrm{~L} . \mathrm{E} . / \mathrm{L} ; \mathrm{S}$ is the monthly salaries, 600 L.E; 144 is the estimated working hours per month. Cost of using Shredder: $\mathrm{C}_{1}=5.56 \mathrm{~L}$.E. $/ \mathrm{h}$. and the Cost of using common tractor: $\mathrm{C}_{2}=$ 21.79 L.E./h. and the total cost of cutting operation $=\mathrm{C}_{1}+\mathrm{C}_{2}=5.56+$ $21.79=27.5$ L.E./h.

\section{CONCLUSION AND RECOMMENDATIONS}

From the above mentioned study, it can recommend the following points for farmer or producer or user following the mentioned order has all the choices according to the prevailing production conditions

1- The proper selection of new material leads to decrease the sharp edge angle of modified knives to $20^{\circ}$ degree without deformation and consequently increasing the cutting efficiency.

2- Maximum cutting efficiency for cotton stalks was $86.4 \%$ at following factors: $1 \mathrm{~mm}$ clearance distance., $20^{\circ}$ degree knife edge angle and 1600 rpm cutting drum speed at $25.27 \%$ moisture content.

3- Minimum fuel consumption rate for cotton stalks was $2.48 \mathrm{~L} / \mathrm{h}$ at following factors: $1 \mathrm{~mm}$ clearance distance, $20^{\circ}$ degree knife edge angle , $1300 \mathrm{rpm}$ cutting drum speed at $25.27 \%$ moisture content.

4- Maximum machine production for cotton stalks was $1.4 \mathrm{ton} / \mathrm{h}$ at following factors: $5 \mathrm{~mm}$ clearance distance, at $20^{\circ}$ degree knife edge angle and $1600 \mathrm{rpm}$ cutting drum speed at $25.27 \%$ moisture content.

5- Maximum cutting efficiency for rice straw was $45.6 \%$ at following factors: $1 \mathrm{~mm}$ clearance distance, $20^{\circ}$ degree knife edge angle ,1600 rpm cutting drum speed at $15.46 \%$ moisture content

6- Minimum fuel consumption rate for rice straw was $3.51 \mathrm{~L} / \mathrm{h}$ at following factors: $1 \mathrm{~mm}$ clearance distance, $20^{\circ}$ degree knife edge angle, $1300 \mathrm{rpm}$ cutting drum speed at $15.46 \%$ moisture content. 
7- Maximum machine production for rice straw was 0.99 ton/h at following factors: $1 \mathrm{~mm}$ clearance distance., $20^{\circ}$ degree knife edge angle $1600 \mathrm{rpm}$ cutting drum speed at $15.46 \%$ moisture content.

\section{REFERENCES}

Arif, El. M. (1999). Development and performance evaluation of a shredder machine for composting. Ph.D. thesis, Agricultural Mechanization Department. Faculty of Agriculture, Ain Shams University.

Chattopadhay P.S. and K.P. Pandey (1992). Experimental verification of impact cutting energy estimated through mathematical modeling. Agric. Mechanization in ASIA 23 (3) 39-42.

El-Awady, M.N.(1978). Engineering of tractors and Agricultural Machinery. Text book. Col.Ag. Ain-Shams Univ., $5^{\text {th }}$ Ed.,:164-167.

Habib, R.A.(2002). Design and performance of cutting tools of chopping Machines of Agricultural Crop residues. Ph.D. Thesis, Mechanical design and production Dept. Fac. of Eng. Cairo Univ.

Hashish, A. E.(1981). A study for machine for crushing and grinding crop residue J. Approp, Technol for Egypt Agr. Small. Agric. Activist min of agric USAID No. 2: 15-32.

Ige, M.T., and M.F.Finner (1976b). Optimization of the performance of cylinder type forage harvester cutterhead. Trans. ASAE, 19 (3) 455460.

Imbabi, A.T. (2001). Field evaluation of combination unit for seed-bed preparation and planting wheat under Egyptian conditions. Misr J.Agric. 18 (2): 261-278.

Kepner. R.A., R. Bainer, and E.L. Barger (1987). Principals of farm machinery, 3d Ed., Avi- Pub. Co. : 315-318.

Prasad, T. and Gupta, C.P. (2005). Mechanical properites of maize stalk as related to harvesting. Jagric Engng Res., 20 (1) 79-87.

Sverker, P. (1987). Mechanics of cutting plant material, An ASAE Monograph numbers 7 in a series published by American Society of Agricultural Engineering.

Yumnam, J., and S. Pratap (1991). Energetic of forage chopping. AMA vol. 22 No. 1, p59-63.

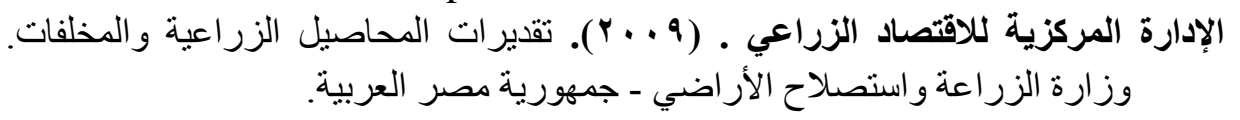




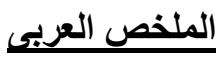 \\ دراسة بعض العوامل الهندسية المرتبطة بأداء الجهاز الفعال في آلة قطع المخلقات الحقلية}

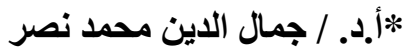

* أ.د / أحمد الراعي إمام سليمان

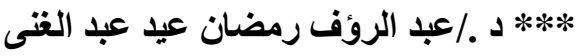

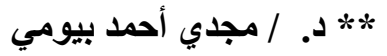

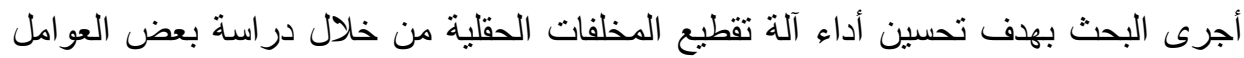

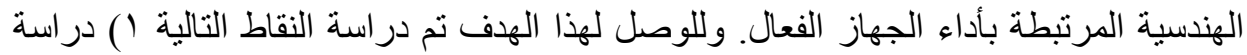

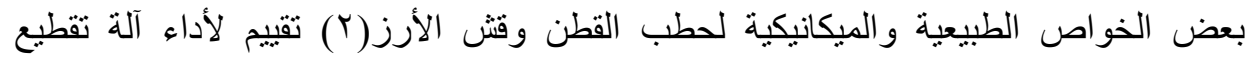

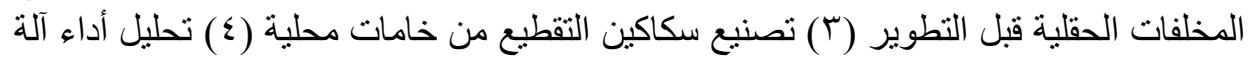

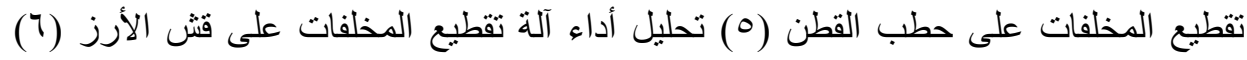

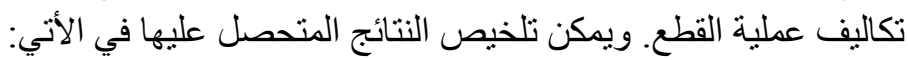

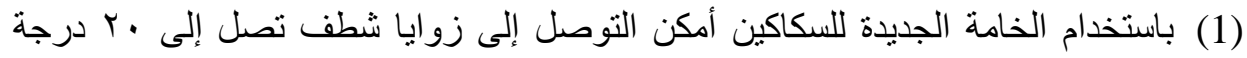

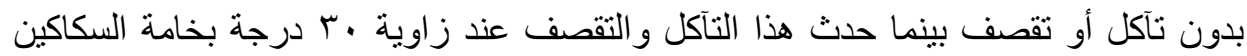

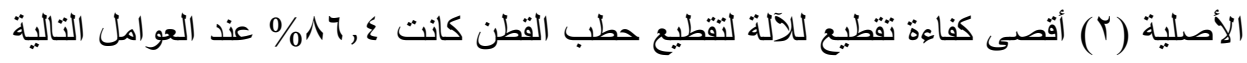

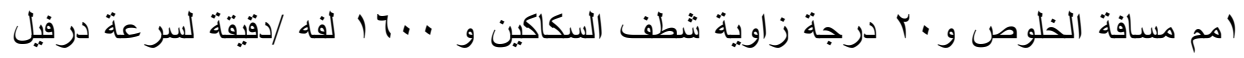

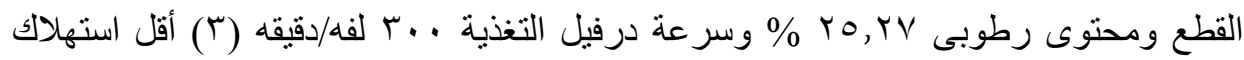

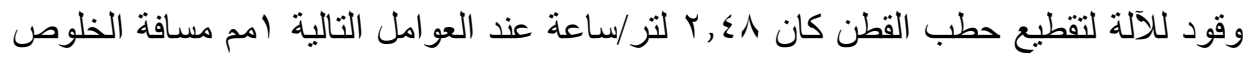

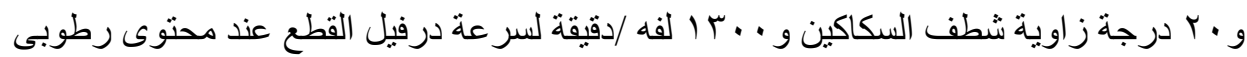

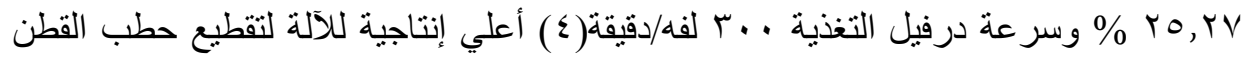

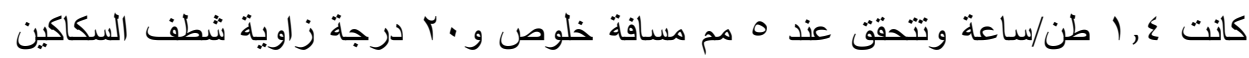

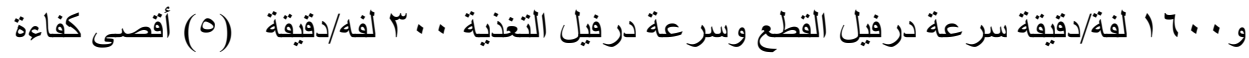

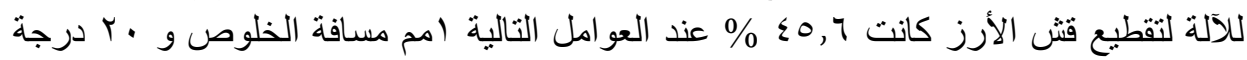

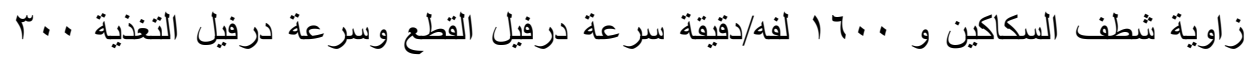

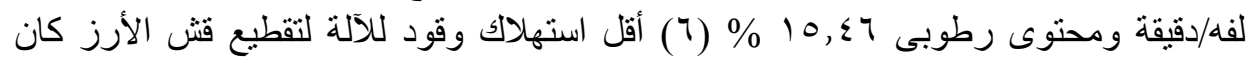

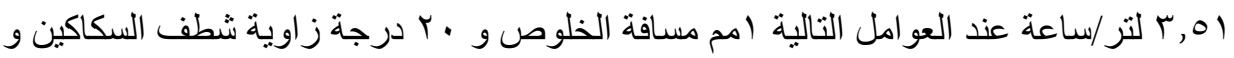

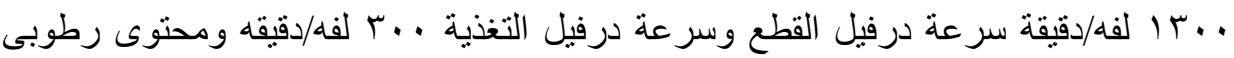


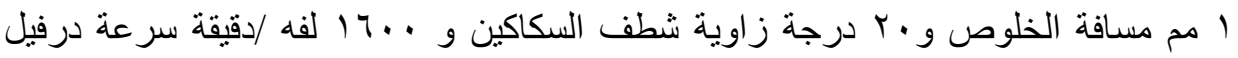

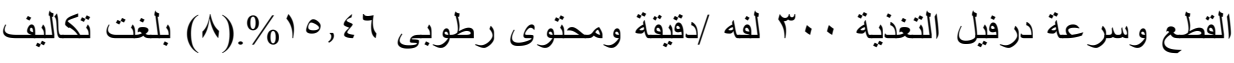
تثغيل الآلة و الجر ار لعملية القطع 27.5 جنيه / ساعة.

\footnotetext{
* *أستاذ الهندسة الزراعية ـ كلية الزراعة - جامعة القاهرة

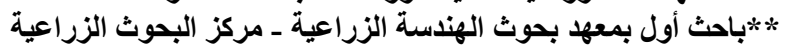

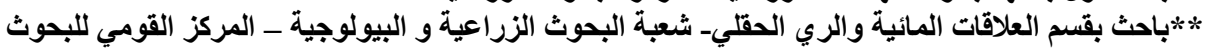

